\title{
STRATEGI PEMBELAJARAN KOOPERATIF DALAM MENINGKATKAN MOTIVASI BELAJAR
}

\author{
Kusen \\ Fakultas Tarbiyah Sekolah Tinggi Agama Islam Negeri Curup \\ Korespondensi: Jl. Dr. AK Gani No. 01, Curup, Bengkulu \\ e-mail: kusen2011@yahoo.com
}

\begin{abstract}
Learning is an interactive process between students and teacher. In order to motivate students to learn, cooperative leaning is really needed. The cooperative leaning gives big advantages to make students more active in the classroom. Students are possible to change ideas. As a result, their motivation are enhanced, their creativity are improved, and their potential were increased. In addition to this, students are not bored in learning. Due to good advanteges of cooperative leaning, it is recommended to use this technique in the classroom
\end{abstract}

Kata Kunci: Pembelajaran, kooperatif, dan motivasi.

\section{PENDAHULUAN}

$\mathrm{S}$ etiap individu memiliki kondisi internal, di mana kondisi internal tersebut turut berperan dalam aktivitas dirinya sehari-hari. Salah satu kondisi internal tersebut adalah motivasi. Menurut Barbara bahwa motivasi sering dikaitkan dengan prestasi akademik sebagai pengaruh kausal dalam kesuksesan seorang individu atau kegagalan pada tugas (Martin dan Briggs, 1986: 200). Bahkan, beberapa pendidik berpendapat bahwa kegagalan individu untuk bekerja sampai potensi dirinya adalah sebagian besar karena kurangnya minat dan atau kurangnya motivasi. Untuk memperbaiki efek kerusakan yang disebabkan oleh kurangnya motivasi, perencana pendidikan sering melakukan reward untuk meningkatkan motivasi misalnya, penghargaan dan pujian, memberikan pengaturan pendidikan yang "memotivasi" dan kondusif untuk belajar, dan mengembangkan bahan-bahan yang merangsang dan menyenangkan. Hasil akhir dari perencanaan tersebut adalah untuk meningkatkan kompetensi akademik dengan meningkatkan prestasi peserta didik melalui motivasi.

Motivasi, dilihat dengan cara ini, yang berarti akhir suatu proses pembelajaran yang ingin dicapai, namun juga dapat ditujukan sebagai produk akhir penting pendidikan diri mereka sendiri, yang sama pentingnya dengan prestasi akademik. Menurut Krathwohl et al menjelaskan bahwa taksonomi saat pengembangan afektif mereka. (Krathwohl, 1964: 118) Mereka menanggapi sebagai salah satu dari lima kategori hasil pembelajaran. Pada tingkat ini kita prihatin mengenai motivasi belajar siswa sebagai fenomena yang terjadi dalam proses pembelajaran. Namun yang diharapkan dalam proses pembelajaran, siswa tidak cukup hanya termotivasi bahwa ia hanya bersedia untuk hadir, tapi mungkin itu benar untuk mengatakan bahwa dia aktif mengikuti. Penulis menyarankan bahwa ini adalah kategori di mana sebagian besar kepentingan tujuan belajar dapat ditemukan. 
Motivasi juga diakui sebagai hasil dari perencanaan pembelajaran. Motivasi mengacu pada upaya yang berkelanjutan, kecenderungan bagi seorang individu untuk bekerja pada tugas tertentu atau tugas yang sama ketika tidak berada di bawah pengaruh langsung dari instruktur, atau jauh dari konteks pembelajaran. Selanjutnya motivasi menyiratkan bahwa seorang individu secara sukarela memilih untuk memelihara atau mempertahankan aktivitas terhadap tugas selama period waktu.

Keberhasilan belajar peserta didik tidak saja dipengaruhi oleh motivasi dalam diri siswa namun perlu ada pengembangan pembelajaran yang dapat memberikan dorongan kepada siswa. Sehubungan dengan hal tersebut pembelajaran kooperatif dapat digunakan dalam pembelajaran tersebut. Sebab pembelajaran kooperatif merupakan pembelajaran yang dapat menciptakan belajar aktif. Teori yang melandasi pembelajaran kooperatif adalah teori konstruktivisme. Menurut Rusman bahwa pada dasarnya pendekatan teori konstruktivisme dalam belajar adalah suatu pendekatan dimana siswa harus secara individual menemukan dan mentransformasikan informasi yang kompleks. (Krathwohl, 1964: 118) Memeriksa informasi dengan aturan yang ada dan merivisinya bila perlu.

Menurut Slavin bahwa pembelajaran kooperatif menggalakkan siswa berinteraksi secara aktif dan positif dalam kelompok. Ini membolehkan pertukaran ide dan pemeriksaan ide sendiri dalam suasana yang kondusif. (Slavin 1983: 5) Dengan demikian, bahwa pendidikan hendaknya mampu mengkondisikan, dan memberikan dorongan untuk dapat mengoptimalkan dan membangkitkan potensi siswa, menumbuhkan aktivitas dan kreativitas siswa, sehingga akan menjamin terjadinya dinamika di dalam proses pembelajaran.

Pembelajaran konstruktivisme menurut Ratna (dalam Ismail), lebih mengutamakan pada pembelajaran siswa yang dihadapkan pada masalah-masalah kompleks untuk dicari solusinya, selanjutnya menemukan bagian-bagian yang lebih sederhana atau keterampilan yang diharapkan. (Ismail 2003: 181) Model pembelajaran dikembangkan dari teori belajar konstruktivisme yang lahir dari gagasan Piaget dan Vigotsky. Menurut Piaget, bahwa pengetahuan itu dibangun dalam pikiran anak.

Berdasarkan model pembelajaran kooperatif ini, guru lebih berperan sebagai fasilitator yang berfungsi sebagai jembatan penghubung ke arah pemahaman yang lebih tinggi, dengan catatan siswa sendiri. Guru tidak hanya memberikan pengetahuan pada siswa, namun juga harus membangun dalam pikirannya. Siswa mempunyai kesempatan untuk mendapatkan pengalaman langsung dalam menerapkan ide-ide mereka, hal tersebut merupakan kesempatan bagi siswa untuk menemukan dan menerapkan ide-ide siswa sendiri.

Lebih lanjut dijelaskan menurut Ratna (dalam Ismail) bahwa pandangan Piaget dan Vigotsky terlihat adanya hakikat sosial dari sebuah proses belajar dan juga tentang penggunaan kelompokkelompok belajar dengan kemampuan anggotanya yang beragam, sehingga terjadi perubahan konseptual. Piaget menekankan bahwa belajar adalah sebuah proses aktif dan pengetahuan disusun di dalam pikiran siswa. Jadi, belajar adalah tindakan kreatif di mana konsep dan kesan dibentuk dengan memikirkan objek dan bereaksi pada peristiwa tersebut. Ini berarti bahwa pentingnya interaksi dengan teman sebaya, melalui pembentukan kelompok belajar. (Ismail 2003: 182) Dengan kelompok belajar 
memberikan kesempatan kepada siswa secara aktif dan kesempatan untuk mengungkapkan sesuatu yang dipikirkan siswa kepada teman akan membantunya untuk melihat sesuatu dengan lebih jelas bahkan melihat ketidaksesuaian pandangan mereka sendiri.

\section{Pengertian Pembelajaran Kooperatif}

Pembelajara kooperatif merupakan bentuk pembelajaran dengan cara siswa belajar dan bekerja dalam kelompokkelompok kecil secara kolaboratif yang anggotanya terdiri dari empat sampai enam siswa dengan struktur kelompok yang bersifat heterogen. Artinya bahwa pembelajaran kooperatif sama dengan kerja kelompok. Menurut Abdulhak (dalam Ismail) menjelaskan bahwa pembelajaran kooperatif dilaksanakan melalui sharing proses antara siswa, sehingga dapat mewujudkan pemahaman bersama diantara siswa belajar itu sendiri, dengan demikian akan tercipta sebuah interaksi yang lebih luas, dalam interaksi dan komunikasi yang dilakukan guru dengan siswa, siswa dengan siswa, demikian juga guru dengan siswa semua warga sekolah.

Menurut Nurul Hayati bahwa pembelajaran kooperatif adalah strategi pembelajaran yang melibatkan partisipasi siswa dalam satu kelompok kecil untuk saling berinteraksi. (Nurul Hayati, 2000: 25) Di mana siswa belajar secara bersama dengan anggotanya. Artinya bahwa siswa memiliki tanggung jawab, bahwa mereka belajar untuk dirinya sendiri dan membantu sesama anggota kelompok untuk belajar. Siswa belajar bersama dalam sebuah kelompok kecil dan mereka dapat melakukannya seorang diri. Pembelajaran kooperatif merupakan strategi pembelajaran yang banyak menarik perhatian kalangan pengajar. Berikut saya sajikan pengertian pembelajaran kooperatif hasil dari terjemahan artikel pembelajaran kooperatif dari gambar berikut:

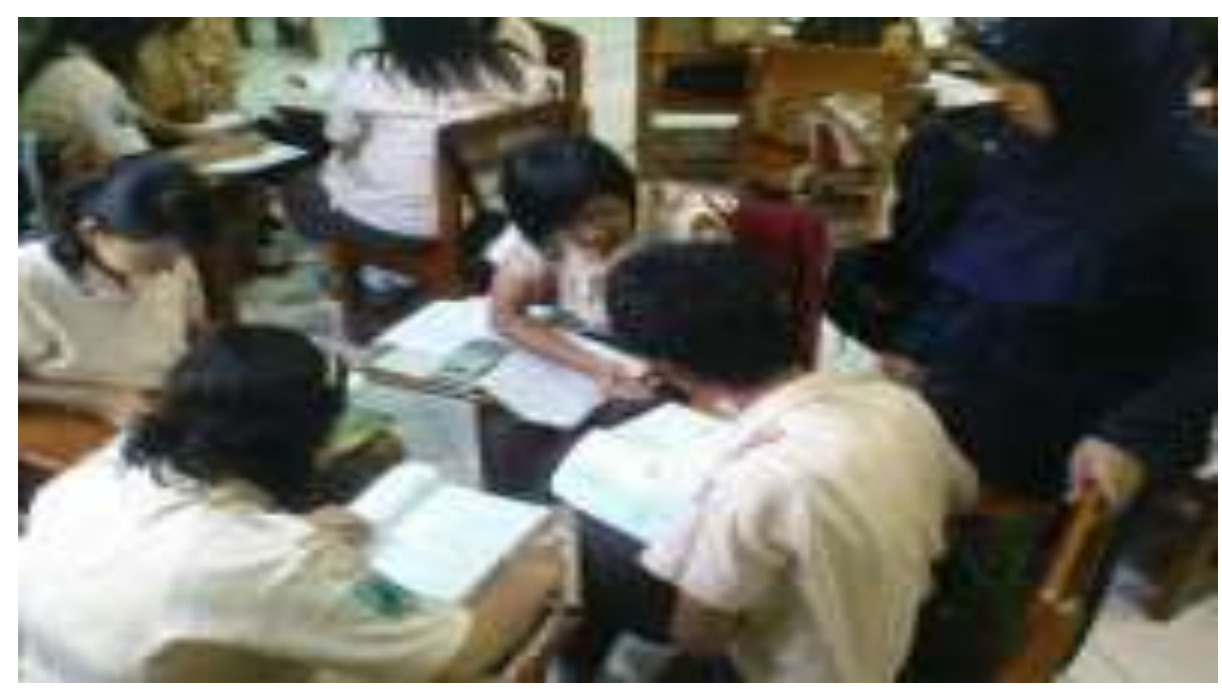

Sumber: http://edtech.kennesaw.edu/intech/cooperativelearning.htm.

Sebagaimana gambar di atas terlihat adanya sekelompok siswa yang saling interaksi satu dengan yang lainnya, dengan demikian dapatlah dipahami bahwa pembelajaran kooperatif adalah strategi pembelajaran yang cukup berhasil pada kelompok-kelompok kecil, di mana pada tiap kelompok tersebut terdiri dari siswa-siswa dari berbagai tingkat kemampuan, melakukan berbagai 
kegiatan belajar untuk meningkatkan pemahaman mereka tentang materi pelajaran yang sedang dipelajari. Setiap anggota kelompok bertanggung jawab untuk tidak hanya belajar apa yang diajarkan tetapi juga untuk membantu siswa lainnya belajar, sehingga bersamasama mencapai keberhasilan. Semua Siswa berusaha sehingga anggota kelompok berhasil memahami dan melengkapinya.

Anggota kelompok berusaha untuk saling menguntungkan sehingga semua anggota kelompok bisa:

1. Merasakan keuntungan dari setiap usaha teman lainnya. (Kesuksesan Anda bermanfaat bagi saya dan keberhasilan saya bermanfaat untuk Anda).

2. Menyadari bahwa semua anggota kelompok mempunyai nasib yang sama. (Tenggelam atau mengapung kita bersama).

3. Tahu bahwa prestasi seseorang ditentukan oleh orang lain dalam satu kelompok. (Kami tidak dapat melakukannya tanpa Anda).

4. Merasa bangga dan merayakan bersama ketika salah satu anggota kelompok mendapatkan keberhasilan (Kami semua merasa sukses atas kesuksesan anda.

\section{Pengertian Motivasi Belajar}

Istilah motivasi menurut Isbandi Rukminto Adi, berasal dari kata motif yang dapat diartikan sebagai kekuatan yang terdapat dalam diri individu, yang menyebabkan individu tersebut bertindak atau berbuat. (Rukminto, 1994: 154) Menurut Gerungan dijelaskan bahwa motif dapat dibedakan menjadi tiga macam, yaitu: 1). Motif biogenetis, yaitu motif yang berasal dari kebutuhan organisme demi kelanjutan hidupnya, misalnya: lapar, haus, kebutuhan akan kegiatan dan istirahat, mengambil nafas, seksualitas, dan sebagainya, 2). Motif sosiogenetis, yaitu motif yang berkembang berasal dari lingkungan kebudayaan setempat. Jadi motif ini tidak berkembang dengan sendirinya, tetapi dipengaruhi oleh lingkungan kebudayaan dimana seseorang bertempat tinggal. Misalnya seseorang berkeinginan mendengarkan musik, makan pecel, dan lain sebagainya, 3). Motif teologis, yaitu dalam motif ini, manusia adalah sebagai makluk berketuhanan, sehingga ada interaksi antara manusia dengan TuhanNya, seperti beribadah, untuk mengabdi kepada Tuhan-Nya dalam merealisasikan norma agama yang dianutnya. (Gerungan. W.A, 1996: 142)

Hampir semua orang akan setuju bahwa keadaan awal merupakan faktor untuk meningkatkan motivasi belajar berikutnya, dan bahwa pengakuan keberhasilan dalam meningkatkan motivasi belajar lebih lanjut untuk belajar lanjutan. Efek ini menumpuk dalam spiral kumulatif atau proses selama periode waktu belajar. Dengan demikian, motivasi mengacu pada kedua ujungnya dan sarana-baik sebab dan akibat (hasil) dari belajar. Menurut Barbara tentang permasalahan stres, baik penyebab atau efek: teori penguatan menekankan desain pembelajaran efektif sehingga keberhasilan pembelajaran dapat diperkuat, sehingga menekankan motivasi sebagai hasil (efek; akhir) dari pembelajaran; penulis yang menekankan gairah kepentingan diawal pembelajaran yang berfokus pada motivasi sebagai penyebab (rata-rata) untuk mempromosikan belajar. (Martin dan Briggs, 1986: 203) Dengan demikian untuk memahami motivasi, ada dua hal yang perlu diperhatikan, yaitu:

1. Motivasi harus ditetapkan pada awal pembelajaran sebagai penyebab atau sarana mempromosikan belajar. Ini 
menekankan arusal, minat, dan relevan.

2. Motivasi adalah efek atau akhir (hasil) dari pembelajaran yang efektif, memberikan bahwa peserta didik merasa upaya mereka berhasil. Ini menekankan penguatan dan harapan.

Berdasarkan pemahaman di atas, dengan motivasi siswa akan mendapatkan hasil belajar yang baik. Motivasi akan senantiasa menentukan intensitas usaha belajar bagi para siswa. Jadi ada tiga fungsi motivasi menurut Sardiman yaitu:

a. Mendorong manusia (siswa) untuk berbuat, jadi sebagai penggerak.

b. Menentukan arah perbuatan.

c. Menyeleksi perbuatan. (Sardjiman, 2005: 85)

Semua itu dapat berfungsi untuk mencapai prestasi belajar, adanya motivasi yang baik dalam belajar akan menunjukkan hasil yang baik. Dengan kata lain, usaha yang tekun dan terutama didasari adanya motivasi, maka siswa belajar melahirkan prestasi yang baik. Intensitas motivasi siswa akan sangat menentukan tingkat pencapaian prestasi belajarnya.

Dengan demikian, melalui pembelajaran kooperaif dipandang sebagai proses pembelajaran yang baik, akan memberikan motivasi kepada siswa. Artinya bahwa ada dalam proses pembelajaran yang bernuansa kooperatif dengan berbagai kelompok kecil untuk bekerja sama, membangun dalam rentang waktu yang terkait perlu untuk dibahas, sehingga proses pembelajaran tersebut dapat meningkatkan motivasi belajar siswa.

Proses pembelajaran kooperatif dibentuk dengan jumlah siswa antara 4 sampai 6 orang siswa. Dengan pembelajaran kooperatif banyak unsur yang perlu perhatikan disamping materi yang disajikan dalam pembelajaran. Ketika kelompok telah dibentuk, maka kerja selanjutnya adalah siswa menentukan sendiri siapa yang menjadi ketua kelompok, untuk mengatur kelompoknya, dengan prinsip kerja tim. Sebab yang dibangun dalam kooperatif adalah kesadaran untuk menerima, dengan melihat apa yang terjadi dalam belajar sehingga dapat membangkitkan motivasi pada diri siswa dalam tim tersebut.

Teori Keller sangat menarik dari teori harapan-nilai, bagaimana kebutuhan individu, kepercayaan, dan harapan mempengaruhi pilihan perilaku. Keller membahas peran penguatan pada motivasi. Ia mewakili penguatan sebagai efek hubungan dari konsekuensi dan evaluasi pada motivasi. Teori Keller adalah memberikan kontribusi yang positif. Ada empat kategori dalam keterkaitan pada motivasi:

\section{Minat;}

Minat untuk mendirikan dan memelihara rasa ingin tahu dan mencapai tingkat optimal gairah pelajar. Keller memberikan strategi khusus untuk meningkatkan rasa ingin tahu, seperti menggunakan masalah novel, membimbing penyelidikan asing tetapi tidak sepenuhnya daerah-daerah yang tidak diketahui, dan menggunakan contohcontoh pribadi tentang pelajar wchich memiliki beberapa ikatan emosional.

\section{Relevansi;}

Relevansi mengacu menghubungkan situasi belajar dengan kebutuhan dan motif pelajar. Ia menyediakan strategi untuk kebutuhan daya, kebutuhan afiliasi, dan kebutuhan berprestasi, ia juga memberikan kondisi untuk strategi instrumental-nilai dan strategi nilai budaya. Beberapa strategi yang berhubungan dengan relevansi meliputi kesempatan untuk sukses sebagai hasil dari upaya, peluang kerjasama dan pilihan pribadi, membantu peserta didik 
dominan dari satu tujuan ke depan, dan menyediakan dukungan sebaya dan kelompok budaya.

\section{Harapan:}

Harapan mengacu menyebabkan satu atribut untuk herbehaviornya atau dan potensi untuk mengulangi atau setidaknya mendekati tugas serupa. Tujuannya adalah keberhasilan toodevelop keyakinan kedepan. Konsep fokus pengendalian, atribusi, learned helplessness, dan sebab-akibat pribadi memainkan peran sentral dalam kategori harapan, dan terlihat jelas dalam strategi. Sebagai contoh, ia menyarankan melampirkan sukses untuk pribadi, attributions internal, dan meningkatkan jumlah pengalaman sukses.

\section{Kepuasan}

Kepuasan konsep (hasil) adalah salah satu yang paling menarik bagi kita, karena paling erat minatnnya dengan motivasi yang berkelanjutan, yang didefinisikan sebagai "motivasi untuk terus mengejar tujuan yang sama" Keller (dalam Barbara). Keller menunjukkan bahwa mengembangkan motivasi intrinsik adalah kunci untuk mempertahankan motivasi, dan bahwa penguatan eksternal memanfaatkan informasi dan bukan pada aspek pengendalian pahala dapat membantu dalam upaya ini. (Martin dan Briggs, 1986: 422)

\section{Teori Pembelajaran Kooperatif dalam Meningkatkan Motivasi Belajar}

\section{John Dewey dan Herbert Thelan}

Pada tahun 1916, John Dewey, menulis buku berjudul "Democracy and Education" Di dalam buku itu dia menyatakan bahwa kelas seharusnya cermin masyarakat yang Iebih besar dan berfungsi sebagai laboratorium untuk belajar tentang kehidupan nyata. Dewey mengharuskan guru menciptakan suatu sistem sosial yang dicirikan dengan prosedur demokrasi dan proses ilmiah di dalam lingkungan belajarnya. Tanggungjawab utama mereka adalah memotivasi siswa untuk bekerja secara kooperatif dan memikirkan masalah sosial penting yang muncul pada hari itu dalam kelas. Di samping upaya pemecahan masalah di dalam kelompok kecil mereka, siswa belajar menghormati satu sama lainnya melalui interaksi.

Pendapat Dewey tersebut dikembangkan oleh Herbert Thelan tahun1954, dengan argumentasi bahwa kelas haruslah merupakan laboratorium atau miniatur demokrasi yang bertujuan mengkaji masalah-masalah sosial dan antar pribadi. Dewey dan Thelan berpendapat bahwa tingkah laku kooperatif merupakan dasar demokrasi, dan sekolah dipandang sebagai laboratorium untuk mengembangkan tingkah laku demokrasi sehingga terjadi rasa tanggung jawab yang sama dalam mencapai keberhasilan.

\section{Gordon Allport dan Relasi antar Kelompok}

Menurut Gordon Alport, aturan hukum saja tidak akan mampu mengurangi kecurigaan antar kelompok dan mendatangkan penerimaan dan pemahaman lebih baik. Oleh karena itu, kontak langsung antar etnis yang terjadi di bawah kondisi status yang selaras dibutuhkan untuk mengurangi kecurigaan ras dan etnis.

Tiga kondisi dasar yang dirumuskan oleh Gordon Allport untuk mencegah terjadinya kecurigaan antar ras dan etnis, yaitu: (a) kontak langsung antar etnik, (b) sama-sama berperan serta di dalam kondisi status yang sama antara anggota dari berbagai kelompok dalam suatu seting tertentu, (c) di mana seting itu secara resmi mendapat persetujuan kerjasama antar-etnis. 
Sehubungan dengan hal di atas, bahwa dalam kelas terdapat berbagai latar belakang siswa yang berbeda, baik suku, agama dan kebudayaan. Ini berarti bahwa perbedaan tersebut menjadi kondisi yang dapat mempengaruhi motivasi belajar, sehingga kebersamaan dalam menerima dan bekerja sama dalam kelas yang dituangkan dalam kelompok kecil dalam belajar dapat memberikan motivasi pada diri siswa.

\section{Belajar Berdasarkan Pengalaman}

Menurut Johnson dan Johnson, belajar berdasarkan pengalaman didasarkan pada tiga asumsi: bahwa anda akan belajar paling baik, jika anda secara pribadi terlibat dalam pengalaman belajar itu, bahwa pengetahuan harus ditemukan oleh anda sendiri apabila pengetahuan itu hendak anda jadikan pengetahuan yang bermakna atau membuat suatu perbedaan dalam tingkah laku anda, dan bahwa komitmen terhadap belajar paling tinggi apabila Anda bebas menetapkan tujuan pembelajaran anda sendiri dan secara aktif mempelajari tujuan itu dalam suatu kerangka tertentu. (Johnson dan Johnson 1994: 21)

Ini berarti bahwa setiap siswa memiliki pengalaman belajar yang berbeda, siswa dapat menemukan belajar mereka dengan pengalaman tersebut sehingga dalam menciptakan kebersamaan perbedaan pengalaman akan menambah pengetahuan satu dengan yang lain.

\section{Tujuan Pembelajaran Kooperatif}

Model pembelajaran kooperatif dikembangkan untuk mencapai setidaktidaknya tiga tujuan pembelajaran, yaitu peningkatan kemampuan akademik, penerimaan terhadap keragaman, dan pengembangan keterampilan sosial.

Sedangkan menurut Louisell dan Descamps, tujuan pembelajaran kooperatif adalah to increase academic achievement, improve relations among students of diverse ethnic backgrounds and abilities, and develop group problem-solving and group process skills. The strategy provides an unusual combination of academic, affective, and social learning outcomes. (Louisell dan Descamps 1992: 212)

Berdasarkan kutipan tersembungi, tujuan pembelajaran kooperatif adalah:

\section{Peningkatan Kemampuan Akademik}

Tujuan pembelajaran kooperatif lebih menekankan pada berbagai macam tujuan sosial, selain itu juga bertujuan untuk meningkatkan kemampuan akademik siswa. Beberapa ahli berpendapat bahwa model ini mampu meningkatkan hasil belajar siswa di bidang akademik dan perubahan norma yang berhubungan dengan hasil belajar.

Robert Slavin mencatat: siswa sering tidak menghargai temannya yang berhasil secara akademis, sementara itu mereka benar-benar menghargai temannya yang menonjol dalam olah raga. Hal ini terjadi karena keberhasilan di dalam olah raga membawa ke-untungan kepada kelompok (tim, sekolah, atau daerah), sementara keberhasilan akademik, keuntungannya hanya bersifat individual. (Slavin, 1983: 10)

Slavin dan para ahli lainnya percaya bahwa memusatkan perhatian pada kelompok pembelajaran kooperatif dapat mengubah norma budaya anak muda dan membuat budaya lebih dapat menerima prestasi menonjol dalam tugas-tugas pembelajaran akademik.

Di samping mengubah norma yang berhubungan dengan hasil belajar/pembelajaran kooperatif dapat memberi keuntungan baik pada siswa kelompok bawah maupun kelompok atas yang bekerja bersama menyelesaikan tugastugas akademik. Siswa kelompok atas 
akan menjadi tutor bagi siswa kelompok bawah, jadi memperoleh bantuan khusus dari teman sebaya yang memiliki orientasi dan bahasa yang sama. Dalam proses tutorial ini, siswa kelompok atas akan meningkat kemampuan akademiknya karena memberi pelayanan sebagai tutor yang membutuhkan pemikiran lebih mendalam tentang hubungan ideaidea yang terdapat di dalam materi tertentu.

Dengan demikian, bahwa dalam kegiatan pembelajaran kooperatif, guru mempunyai kegiatan, tidak hanya menguji sebagaimana metode ceramah, Tapi guru yaitu membangun kemampuan siswa untuk memasuki ranah kognitif, sehingga terbentuklah rasa ingin tahu siswa. Ketika proses pembelajaran itu berlangsung, ada sesuatu yang terjadi, siswa ada yang senang dalam membelajaran tersebut ada juga yang tidak, posisi guru tidak untuk melengkapi permasalahan yang terjadi, namun guru mencari cela yang luang itu, agar siswa mencari cela yang luang tersebut, guru hanya mencoba membuat terjadinya cela atau membuka peluang, kemudian diadakan diskusi di dalam kelompok tersebut. Sekarang ini guru jarang untuk membuka peluang dalam permasalahan dalam materi tersebut, untuk itu perlu dibangun agar siswa merasa andil dalam kelompoknya, yang memiliki prestasi akademik, memberikan kesempatan kepada yang lemah akademiknya, antara yang satu dengan yang lain saling mengisi dan menerima, sehingga motivasi belajar siswa meningkat.

\section{Penerimaan terhadap Keragaman Individu}

Tujuan kedua dari model pembelajaran kooperatif ialah penerimaan yang luas terhadap orang yang berbeda menurut ras, budaya, kelas sosial, kemampuan, maupun ketidakmampuan.
Goldon Allport, mengatakan bahwa kontak fisik saja di antara orang-orang yang berbeda ras atau kelompok etnik tidaklah cukup untuk mengurangi kecurigaan dan perbedaan. (Goldon Allport, 1954: 23) Pembelajaran kooperatif memberi peluang kepada siswa yang berbeda latar belakang dan kondisi untuk bekerja saling bergantung satu sama lain atas tugas-tugas bersama, dan melalui penggunaan struktur penghargaan kooperalif, belajar untuk menghargai satu sama lain.

Ketika para siswa dapat menerima satu dengan yang lain, maka pembelajaran yang dilakukan akan memerikan motivasi pada diri siswa, namun jika dalam kelompok belajar ada yang tidak nyaman, maka prestasi belajar siswa tentu akan berdampak kurang baik. Untuk itu, dalam pembelajaran kooperatif, diperlukan saling menerima satu dengan lainnya, sehingga siswa dapat termotivasi dalam belajar.

\section{Pengembangan Keterampilan Sosial}

Tujuan ketiga dari pembelajaran kooperatif ialah untuk mengajarkan kepada siswa keterampilan kerjasama, kolaborasi, dan pemecahan masalah sosial bersama. Keterampilan ini amat penting untuk dimiliki siswa di dalam masyarakat dimana banyak kerja orang dewasa sebagian besar dilakukan dalam organisasi yang saling bergantung satu sama lain dan dimana masyarakat secara budaya semakin beragam, serta sarat dengan berbagai permasalahan sosial yang menuntut secara cepat dipecahkan.

Sementara itu, banyak anak muda dan orang dewasa masih kurang dalam keterampilan sosial. Situasi ini dibuktikan dengan begitu sering pertikaian kecil antara individu dapat mengakibatkan tindak kekerasan atau betapa sering orang menyatakan ketidakpuasan pada saat diminta untuk bekerja dalam situasi kooperatif. 
Dengan demikian, bahwa ranah kooperatif jelas merupakan area afeksi, hal tersebut dapat dilihat dari segi produk, dimana siswa dapat memperlihatkan sikap dari sisi menerima untuk bekerjasama dalam tim, sebab konsep dasar pembelajaran kooperatif adalah teman sejawat. Dengan pembelajaran kooperatif nanti produknya adalah jika diterima proses pembelajaran tersebut berupa kesadaran, keharmonisan, dan kesenangan. Sebab yang dicari dalam proses pembelajaran juga menemukan makna.

\section{Langkah-langkah Pembelajaran Kooperatif}

Menurut Rusman menjelaskan bahwa terdapat 6 langkah utama atau tahapan di dalam pembelajaran koope- ratif. Pembelajaran dimulai dengan guru menyampaikan tujuan pembelajaran dan memotivasi siswa untuk belajar. Tahap ini diikuti oleh penyajian informasi; seringkali dengan bahan bacaan daripada secara verbal. Selanjutnya siswa dikelompokkan kedalam tim-tim belajar. Tahap ini diikuti bimbingan guru pada saat siswa bekerja bersama untuk menyelesaikan tugas bersama mereka. Tahap terakhir pembelajaran kooperatif meliputi presentasi hasil akhir kerja kelompok, atau evaluasi tentang apa yang telah mereka pelajari dan memberi penghargaan terhadap usaha-usaha kelompok maupun individu. Langkahlangkah pembelajaran kooperatif secara sederhana seperti dalam Tabel 1.1. (Rusman, 2010: 211)

Tabel 1 .1. Langkah-langkah Model Pembelajaran Kooperatif dalam meningkatkan Motivasi belajar

\begin{tabular}{ll}
\hline \multicolumn{1}{c}{ Tahap } & \multicolumn{1}{c}{ Kegiatan Guru } \\
\hline $\begin{array}{l}\text { Tahap-1 } \\
\text { Menyampaikan tujuan } \\
\text { dan memotivasi siswa }\end{array}$ & $\begin{array}{l}\text { Guru menyampaikan tujuan pelajaran yang ingin } \\
\text { dicapai pada pelajaran tersebut dan memotivasi } \\
\text { siswa belajar. }\end{array}$ \\
\hline $\begin{array}{l}\text { Tahap-2 } \\
\text { Menyajikan informasi }\end{array}$ & $\begin{array}{l}\text { Guru menyajikan informasi kepada siswa dengan } \\
\text { jalan demonstrasi atau lewat bahan bacaan. }\end{array}$ \\
\hline $\begin{array}{l}\text { Tahap-3 } \\
\text { Mengorganisasikan siswa } \\
\text { ke dalam kelompok- } \\
\text { kelompok belajar }\end{array}$ & $\begin{array}{l}\text { Guru menjelaskan kepada siswa bagaimana } \\
\text { caranya membentuk kelompok belajar dan } \\
\text { membantu setiap kelompok agar melakukan } \\
\text { transisi secara efisien. }\end{array}$ \\
\hline $\begin{array}{l}\text { Tahap-4 } \\
\text { Membimbing kelompok } \\
\text { bekerja dan belajar }\end{array}$ & $\begin{array}{l}\text { Guru membimbing kelompok-kelompok belajar } \\
\text { pada saat mereka mengerjakan tugas mereka. }\end{array}$ \\
\hline $\begin{array}{l}\text { Tahap-5 } \\
\text { Evaluasi }\end{array}$ & $\begin{array}{l}\text { Guru mengevaluasi hasil belajar tentang materi } \\
\text { yang telah dipelajari atau masing-masing } \\
\text { kelompok mempresentasikan hasil kerjanya. }\end{array}$ \\
\hline $\begin{array}{l}\text { Tahap-6 } \\
\text { Memberikan penghargaan }\end{array}$ & $\begin{array}{l}\text { Guru mencari cara-cara untuk menghargai baik } \\
\text { upaya maupun hasil belajar individu dan } \\
\text { kelompok. }\end{array}$ \\
\hline
\end{tabular}




\section{Pendekatan dalam Pembelajaran Kooperatif dalam Meningkatkan Motivasi}

Sebagaimana disebutkan sebelumnya, bahwa beberapa pendekatan yang bisa dilakukan guru dalam pembelajaran kooperatif adalah STAD, JIGSAW, investigasi kelompok, dan pendekatan struktural.

\section{Student Teams Achievement Division (STAD)}

STAD dikembangkan oleh Robert Slavin, dan merupakan pendekatan pembelajaran kooperatif yang paling sederhana. Guru yang menggunakan STAD, yang mengacu pada belajar kelompok siswa, menyajikan informasi akademik baru kepada siswa setiap minggu menggunakan presentasi verbal atau teks. Siswa dalam suatu kelas tertentu dipecah menjadi kelompok dengan anggota 4-5 orang, setiap kelompok haruslah heterogen, terdiri dari laki-laki dan perempuan, berasal dari berbagai suku, memiliki kemampuan tinggi, sedang, dan rendah. Anggota tim menggunakan lembar kegiatan atau perangkat pembelajaran yang lain untuk menuntaskan materi pelajarannya dan kemudian saling membantu satu sama lain untuk memahami bahan pelajaran melalui tutorial, kuis, satu sama lain dan atau melakukan diskusi. Secara individual setiap minggu atau setiap 2 minggu siswa diberi kuis. Kuis itu diskor, dan tiap individu diberi skor perkembangan.

Skor perkembangan ini tidak berdasarkan pada skor mutlak siswa, tetapi berdasarkan pada seberapa jauh skor itu melampaui rata-rata skor siswa yang lalu. Setiap minggu pada suatu lembar penilaian singkat atau dengan cara lain, diumumkan tim-tim dengan skor tertinggi, siswa yang mencapai skor perkembangan tinggi, atau siswa yang mencapai skor sempurna pada kuis-kuis itu. Kadang-kadang seluruh tim yang mencapai kriteria tertentu dicantumkan dalam lembar itu.

Dengan demikian para siswa terlihat dalam perkembangannya, ada bagus, sedang bahkan kurang. Maka guru dapat memberikan motivasi dalam diri siswa untuk meningkatkan pembelajaran ketika siswa ini kurang dalam belajar.

\section{Jigsaw}

Jigsaw telah dikembangkan Elliot Aronson, kemudian diadaptasi oleh Slavin. Dalam penerapan jigsaw, siswa dibagi berkelompok dengan 5 atau 6 anggota kelompok belajar heterogen. Materi pembelajaran diberikan kepada siswa dalam bentuk teks. Setiap anggota bertanggung jawab untuk mempelajari bagian tertentu bahan yang diberikan itu. Anggota dari kelompok lain yang mendapat tugas topik yang sama berkumpul dan berdiskusi tentang topik tersebut. Kelompok ini disebut kelompok ahli.

Selanjut anggota tim ahli ini kembali ke kelompok asal dan mengajarkan apa yang telah dipelajarinya dan didiskusikan di dalam kelompok ahlinya untuk diajarkan kepada teman kelompoknya sendiri. Menyusul pertemuan dan diskusi kelompok asal, siswa-siswa itu dikenai kuis secara individual tentang materi belajar. Dalam Jigsaw versi Slavin, skor tim menggunakan prosedur skoring yang sama dengan STAD. Tim dan individu dengan skor-tinggi mendapat pengakuan dalam lembar pengakuan mingguan atau dengan cara lain. Secara sederhana pendekatan Jigsaw digambarkan dalam pola sebagai berikut. 


\section{Investigasi Kelompok (IK)}

Investigasi kelompok merupakan model pembelajaran kooperatif yang paling kompleks. Model ini dikembangkan pertama kali oleh Thelan dan Sharan. Pembelajaran kooperatif dalam model investigasi kelompok siswa tidak hanya bekerja sama namun terlibat merencanakan baik topik untuk dipelajari dan prosedur penyelidikan yang digunakan.

Pendekatan ini memerlukan norma dan struktur kelas yang lebih rumit daripada pendekatan yang lebih berpusat pada guru. Pendekatan ini juga memerlukan mengajar siswa keterampilan komunikasi dan proses kelompok yang baik.

Penerapan IK diawali dengan guru membagi kelas menjadi kelompokkelompok dengan anggota 5 atau 6 siswa yang heterogen. Dalam beberapa kasus, bagaimanapun juga, kelompok dapat dibentuk dengan mempertimbangkan keakraban persabatan atau minat yang sama dalam topik tertentu. Selanjutnya siswa memilih topik untuk diselidiki, melakukan penyelidikan yang mendalam atas topik yang dipilih itu. Selanjutnya menyiapkan dan mempresentasikan laporannya kepada seluruh kelas. Sharan dkk telah menetapkan enam tahap IK seperti berikut ini: (Sharan dkk, 1984)

\section{a. Pilihan Topik}

Siswa memilih subtopik khusus di dalam suatu daerah, masalah umum yang biasanya ditetapkan oleh guru. Selanjutnya siswa diorganisasikan menjadi dua sampai enam kelompok menjadi yang berorientasi tugas. Komposisi kelompok hendaknya heterogen secara akademis maupun etnis.

\section{b. Perencanaan kooperatif}

Siswa dan guru merencanakan prosedur pembelajaran, tugas, dan tujuan khusus yang konsisten dengan subtopik yang telah dipilih pada tahap pertama.

\section{c. Implementasi}

Siswa menerapkan rencana yang telah dikembangkan di dalam tahap kedua. Kegiatan pembelajaran hendaknya melibatkan ragam aktivitas dan keterampilan yang luas dan hendaknya mengarahkan siswa kepada jenis-jenis sumber belajar yang berbeda baik di dalam atau di luar sekolah. Guru secara ketat mengikuti kemajuan tiap kelompok dan menawarkan bantuan bila diperlukan.

\section{d. Analisis dan sintesis.}

Siswa menganalisis dan mengevaluasi informasi yang diperoleh dan merencanakan bagaimana informasi tersebut diringkas dari disajikan dengan cara yang menarik sebagai bahan untuk dipresentasikan kepada seluruh kelas.

\section{e. Presentasi hasil final.}

Beberapa kelompok menyajikan hasil penyelidikannya dengan cara yang menarik kepada seluruh kelas, dengan tujuan agar siswa saling terlibat satu sama lain dalam pekerjaan dan memperoleh perspektif luas pada topik itu.

\section{f. Evaluasi}

Dalam hal kelompok-kelompok menangani aspek yang berbeda dari topik yang sama, siswa dan guru mengevaluasi tiap kontribusi kelompok terhadap kerja kelas sebagai suatu keseluruhan. Evaluasi yang dilakukan dapat berupa penilaian individual atau kelompok.

\section{Pendekatan Struktural}

Pendekatan ini dikembangkan oleh Spencer Kagen dkk. Meskipun memiliki banyak persamaan dengan pendekatan yang lain, namun pendekatan ini memberi penekanan pada penggunaan struktur tertentu yang dirancang untuk mempengaruhi pola interaksi siswa. 
Struktur yang dikembangkan oleh Kagen ini dimaksudkan sebagai alternatif terhadap struktur kelas tradisional, seperti resitasi, di mana guru mengajukan pertanyaan kepada seluruh kelas dan siswa memberikan jawaban setelah mengangkat tangan dan ditunjuk. Struktur yang dikembangkan oleh Kagen ini menghendaki siswa bekerja saling membantu dalam kelompok kecil dan lebih dicirikan oleh penghargaan kooperatif, daripada penghargaan individual.

Ada struktur yang dikembangkan untuk meningkatkan perolehan isi akademik, dan ada struktur yang dirancang untuk mengajarkan keteram- pilan sosial atau keterampilan kelompok. Dua macam struktur yang terkenal, adalah think-pair-share dan numberedhead-together, yang dapat digunakan oleh guru untuk mengajarkan isi akademik atau untuk mengecek pemahaman siswa terhadap isi tertentu. Sedangkan active listening dan time token, merupakan dua contoh struktur yang dikembangkan untuk mengajarkan keterampilan sosial.

Berdasarkan paparan di atas, perbandingan secara sederhana dari keempat pendekatan dalam pembelajaran kooperatif seperti dalam 1. 2 .

Tabel 1. 2. Perbandingan Empat pendekatan dalam Pembelajaran Kooperatif

\begin{tabular}{|c|c|c|c|c|}
\hline & STAD & JIGSAW & $\begin{array}{l}\text { INVESTIGASIKE } \\
\text { LOMPOK }\end{array}$ & $\begin{array}{l}\text { PENDEKATA } \\
\text { N STRUKTUR }\end{array}$ \\
\hline $\begin{array}{l}\text { Tujuan } \\
\text { Kognitif }\end{array}$ & $\begin{array}{l}\text { Informasi } \\
\text { akademik } \\
\text { sederhana }\end{array}$ & $\begin{array}{l}\text { Informasi } \\
\text { akademik } \\
\text { sederhana }\end{array}$ & $\begin{array}{l}\text { Informasi akade- } \\
\text { mik tingkat tinggi } \\
\text { dan keterampilan } \\
\text { inkuiri }\end{array}$ & $\begin{array}{l}\text { Informasi } \\
\text { akademik } \\
\text { sederhana }\end{array}$ \\
\hline $\begin{array}{l}\text { Tujuan } \\
\text { Sosial }\end{array}$ & $\begin{array}{l}\text { Kerja kelom- } \\
\text { pok dan kerja- } \\
\text { sama }\end{array}$ & $\begin{array}{l}\text { Kerja kelompok } \\
\text { kerjasama }\end{array}$ & $\begin{array}{lr}\text { Kerjasama } & \text { dalam } \\
\text { kelompok } & \text { kom- } \\
\text { pleks } & \end{array}$ & $\begin{array}{l}\text { Keterampilan } \\
\text { kelompok dan } \\
\text { ke-terampilan } \\
\text { sosial }\end{array}$ \\
\hline $\begin{array}{l}\text { Struktur } \\
\text { Tim }\end{array}$ & $\begin{array}{l}\text { Kelompok } \\
\text { belajar hete- } \\
\text { rogendengan } \\
4-5 \text { orang } \\
\text { anggota }\end{array}$ & $\begin{array}{l}\text { Kelompok } \\
\text { belajar hetero- } \\
\text { gen dengan } 5 \text { - } 6 \\
\text { orang anggota } \\
\text { menggunakan } \\
\text { pola kelompok } \\
\text { "asal" dan } \\
\text { kelompok "ahli" }\end{array}$ & $\begin{array}{l}\text { Kelompok belajar } \\
\text { dengan 5-6 } \\
\text { anggota homogen }\end{array}$ & $\begin{array}{l}\text { Bervariasi } \\
\text { berdua, bertiga, } \\
\text { kelompok } \\
\text { dengan 4-6 } \\
\text { anggota }\end{array}$ \\
\hline $\begin{array}{l}\text { Pemilihan } \\
\text { Topic } \\
\text { pelajaran } \\
\end{array}$ & $\begin{array}{l}\text { Biasanya } \\
\text { guru }\end{array}$ & Biasanya guru & Biasanya siswa & Biasanya guru \\
\hline $\begin{array}{l}\text { Tugas } \\
\text { Utama }\end{array}$ & $\begin{array}{l}\text { Siswa dapat } \\
\text { menggunakan } \\
\text { lembar kegiat- } \\
\text { an dan saling } \\
\text { membantu } \\
\text { untuk menun- } \\
\text { taskan materi } \\
\text { belajarnya }\end{array}$ & $\begin{array}{l}\text { Siswa mempe- } \\
\text { lajari materi } \\
\text { dalam kelompok } \\
\text { ahli kemudian } \\
\text { mem-bantu } \\
\text { anggota kelom- } \\
\text { pok asal mem- } \\
\text { pelajari materi }\end{array}$ & $\begin{array}{lr}\text { Siswa menyeIe- } \\
\text { saikan } \\
\text { kompleks }\end{array}$ & $\begin{array}{l}\text { Siswa menger- } \\
\text { jakan tugas- } \\
\text { tugas yang di } \\
\text { berikan sosial } \\
\text { dan kognitif }\end{array}$ \\
\hline
\end{tabular}




\begin{tabular}{lllll}
\hline Penilaian & Tes mingguan & $\begin{array}{l}\text { Bervariasi, dapat } \\
\text { berupa } \\
\text { mingguan }\end{array}$ & $\begin{array}{l}\text { Menyelesaikan } \\
\text { proyek dan me- } \\
\text { nulis laporan, da- } \\
\text { pat mengguna-kan } \\
\text { tes essay. }\end{array}$ & Bervariasi \\
\hline Pengakuan & $\begin{array}{l}\text { Lembar } \\
\text { pengetahuan } \\
\text { dan publikasi }\end{array}$ & Publikasi lain & $\begin{array}{l}\text { Lembar } \\
\text { pengakuan dan } \\
\text { publikasi lain }\end{array}$ & Bervariasi \\
\hline
\end{tabular}

Dalam menggunakan pembelajaran kooperatif di dalam kelas, guru perlu memperhatikan beberapa prinsip dasar, (Nur dkk, 2000: 20) yaitu:

1). Perumusan tujuan belajar siswa harus jelas

Perumusan tujuan pembelajaran harus disesuaikan dengan tujuan pembelajaran tersebut, yang menyangkut pemahaman, sikap, dan proses dalam bekerjasama. Hal tersebut perlu dilakukan oleh guru sebelum kelompok belajar terbentuk.

2). Penerimaan yang menyeluruh tentang tujuan belajar

Guru hendaknya mampu mengkondisikan kelas agar siswa menerima tujuan pembelajaran. Dengan demikian, bahwa semua siswa agar mengetahui dan menerima kenyataan bahwa setiap orang dalam kelompoknya menerima dirinya untuk bekerja sama dalam mempelajari seperangkat pengetahuan dan keterampilan yang telah ditetapkan untuk dipelajari.

3). Ketergantungan yang bersifat Positif

Guru hendaknya mampu merancang struktur kelompok dan tugas-tugas kelompok yang memungkinkan setiap siswa untuk belajar dan mengevaluasi dirinya dan teman kelompoknya dalam penguasaan dan kemampuan memahami materi pelajaran. Dengan demikian, ada ketergantungan secara positif pada anggota kelompok lainnya dalam mempelajari dan menyelesaikan tugas-tugas yang diberikan oleh guru.
4). Interaksi yang bersifat terbuka

Dalam kelompok belajar, interaksi yang terjadi bersifat langsung dan terbuka dalam mendiskusikan materi dan tugas-tugas yang diberikan oleh guru. Suasana belajar tersebut akan menumbuhkembangkan sikap ketergantungan yang positif dan keterbukaan di kalangan siswa untuk memperoleh keberhasilan dalam belajarnya.

5). Kelompok bersifat keterogen

Dalam pembentukan kelompok belajar, keanggotaan kelompok harus bersifat heterogen, sehingga interaksi kerja sama yang terjadi merupakan akumulasi dari berbagai karakteristik siswa yang berbeda, sehingga dalam suasana belajar dikelas, akan menumbuhkembangkan nilai, sikap, moral, dan perilaku siswa.

Unsur-unsur dasar pembelajaran kooperatif adalah: (1) siswa dalam kelompoknya harus beranggapan bahwa mereka "sehidup sepenanggungan bersama; (2) siswa bertanggung jawab atas segala sesuatu di dalam kelompoknya, seperti milik mereka sendiri; (3) siswa harus melihat bahwa semua anggota di dalam kelompoknya memiliki tujuan yang sama; (4) siswa harus membagi tugas dan tanggung jawab yang sama di antara anggota kelompoknya; (5) siswa akan dikenakan evaluasi atau diberikan hadiah/penghargaan yang juga akan dikenakan untuk semua anggota kelompok; (6) siswa berbagi kepemimpinan dan mereka membutuhkan keterampilan untuk belajar bersama selama proses belajarnya; dan (7) siswa akan 
diminta mempertanggungjawabkan secara individual materi yang ditangani dalam kelompok kooperatif.

Menurut Nur bahwa proses pembelajaran yang menggunakan model kooperatif memiliki ciri-ciri: (1) siswa bekerja dalam kelompok secara kooperatif untuk menuntaskan materi belajarnya; (2) kelompok dibentuk dari siswa yang memiliki kemampuan tinggi, sedang, dan rendah; (3) bilamana mungkin, anggota kelompok berasal dari ras, budaya, suku, jenis kelamin berbedabeda; dan (4) penghargaan lebih berorientasi kelompok ketimbang individu. (Nur dkk, 2000: 20)
Menurut Nurul Hayati dijelaskan bahwa ada lima unsur yang ada dalam pembelajaran kooperatif, yaitu: a) ketergantungan yang positif, b) pertanggung jawaban individual, c) kemampuan bersosialisasi, d) tatap muka, dan e) evaluasi proses kelompok. (Nurul Hayati, 2000: 28)

Kemudian setelah itu, langkah yang digambarkan dari bagai di atas, diterapkan pada materi yang ada dalam silabus pembelajaran. Untuk lebih jelasnya dapat dilihat dalam bagan berikut:

Intergrasi Kategori Pembelajaran Kooperatif dalam meningkatkan Motivasi

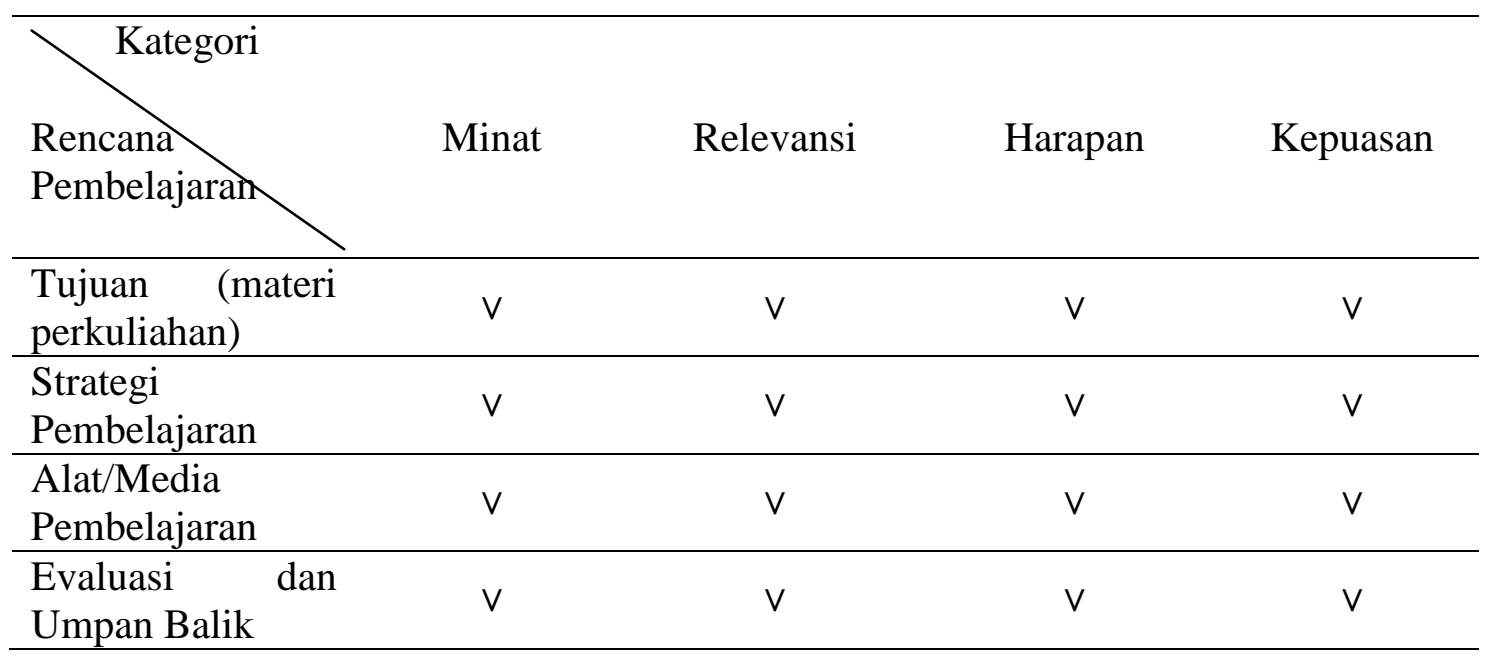

Menurut Keller (dalam Barbara) ada lima strategi penting, dan termasuk penjelasan masing-masing, yaitu:

a. Untuk menjaga kepuasan intrinsik dengan pembelajaran, tugas-endogen daripada penghargaan tugas-eksogen digunakan

b. Untuk menjaga kepuasan intrinsik dengan pembelajaran, gunakan tak terduga, hadiah non-kontingen (kecuali dengan tugas menjemukkan ...)

c. Untuk menjaga kepuasan intrinsik dengan pembelajaran, gunakan pujian verbal dan umpan balik informatif daripada ancaman, pengawasan, atau evaluasi kinerja eksternal;

d. Untuk menjaga kualitas kinerja, gunakan untuk memotivasi umpan balik berikut responnya;

e. Untuk meningkatkan kualitas kinerja, menentukan pertumbuhan siswa (korektif) umpan balik ketika akan langsung pembelajaran, biasanya hanya kesempatan berikutnya untuk berlatih. (Barbara, 1986: 427)

Keller (dalam Barbara) juga menggunakan istilah minat dalam model perencanaan motivasi. (Barbara, 1986: 39) Ini adalah yang pertama dari konsep- 
konsep motivasi yang membahas oleh Keller. Dia menggambarkan keingintahuan epistemik sebagai elemen kunci dari minat. keingintahuan epistemik "merujuk sebagai hasil dari stimulasi rasa ingin tahu". Konsep ini tampaknya terkait erat dengan atau langkah pertama dalam mempertahankan atau selanjutnya motivasi, tetapi juga paralel, sebagian, beberapa Krathwohl et al. tujuan di mana siswa terlibat secara sukarela dalam mengejar atau mencari fenomena. Salah satu strategi Keller memberikan untuk membangkitkan dan memelihara rasa ingin tahu adalah untuk memberikan kesempatan bagi siswa untuk belajar lebih banyak tentang topik yang telah mereka ketahui atau percayai, dan memberikan mereka beberapa pengalaman dengan asing dan tak terduga. Hal ini dalam beberapa hal mirip dengan "jangkauan penerimaan" strategi perubahan sikap. Strategi tersebut melibatkan menyediakan informasi dalam kisaran pelajar penerimaan, dan oleh succesiveapproximations, bergerak individu di luar rentang penerimaan, yaitu, memberi mereka "dosis moderat dari asing dan tak terduga Keller (Barbara, 1982: 402).

Strategi lain Keller memberikan untuk mempertahankan rasa ingin tahu adalah:

1. Memberikan contoh orang-orang yang nyata dan masalah kehidupan nyata.

2. Menyediakan komponen pribadi atau emosional untuk latihan dan material.

3. Gunakan ambigu, paradoks, situasi baru dan atau peristiwa.

Keller juga membahas nilai instrumental yang berkaitan dengan contomuing motivasi. Nilai Instrumental "mengacu pada peningkatan motivasi untuk mencapai tujuan segera bila dianggap langkah yang diperlukan untuk mencapai tujuan masa depan yang diinginkan". (Barbara, 1986: 408) Dia menyarankan bahwa dengan jelas menjelas- kan bagaimana satu tujuan dihubungkan ke yang lain dan bagaimana pemenuhan satu tujuan mengarah pada pemenuhan tujuan masa depan yang diinginkan akan berdampak pada motivasi terus.

Harapan untuk sukses juga menyebabkan motivasi berkelanjutan. (Barbara, 1986: 409) Siswa yang merasa bahwa mereka memiliki kontrol pribadi atas berhasil menyelesaikan tugas belajar dan yang percaya bahwa kesuksesan mereka berhubungan dengan kemampuan pribadi dan usaha akan cenderung bertahan lebih lama daripada mereka yang merasa mereka sedikit kontrol, atau mereka yang percaya bahwa kesuksesan mereka adalah karena faktor eksternal. Akhirnya, kepuasan intrinsik merupakan kunci untuk mengembangkan dan mempertahankan motivasi. (Barbara, 1986: 421) Hal ini ditambah dengan reinformant ditujukan untuk memberikan informasi daripada mengendalikan pelajar dapat menyebabkan motivasi yang berkelanjutan. Sebelumnya, kami pun mencatat beberapa strategi kunci diberikan oleh Keller untuk mempertahankan kepuasan intrinsik.

Implikasi pendidikan sangat memprihatinkan di sekitar menjaga minat dan motivasi terus. difokuskan pada konsep keingintahuan epistemis, nilai instrumental, harapan untuk sukses, dan kepuasan intrinsik. Menggunakan konsepkonsep yang hadir pada kondisi pembelajaran terus memotivasi, yaitu:

\section{Internal Bersyarat}

Menurut Barbara (Barbara, 1986: 207) menjelaskan bahwa internal bersyarat untuk kepentingan motivasi meliputi:

1. Keterampilan intelektual dan informasi verbal yang diperlukan untuk mencapai keberhasilan pada tugastugas di mana tujuannya adalah untuk meningkatkan motivasi untuk belajar lebih lanjut. 
2. Kemampuan kognitif yang memungkinkan peserta didik untuk membedakan antara penyebab internal dan eksternal. Misalnya, anakanak muda ometimes tidak dapat membedakan antara kemampuan dan usaha.

3. Kemampuan untuk membedakan antara penghargaan dan non-penghargaan, dan atau kemampuan untuk memberikan contoh penghargaan pribadi.

\section{Eksternal Bersyarat}

Menurut Barbara (1986: 207) menjelaskan bahwa kondisional eksternal adalah sebagai berikut:

1. Pelajar, ajarkan cara untuk menghargai diri untuk penyelesaian tugas.

2. Tunjukkan bagaimana untuk mencocokkan tugas untuk kebutuhan pribadi sekarang dan masa depan dan nilai.

3. Diskusikan cara untuk memotivasi diri sendiri untuk melakukan tugas-tugas yang tidak menyenangkan. Sebagai contoh, menunjukkan peserta didik bagaimana link tugas-tugas yang tidak diinginkan untuk kebutuhan masa depan, keinginan, ingin; pelajar menunjukkan cara memecahkan besar menjadi unit yang lebih kecil, dan memperkuat setiap langkah.

4. Gunakan kelas sebagai cara untuk menunjukkan kepada peserta didik bagaimana menerapkan prinsip Premack untuk belajar mereka sendiri, dengan penghargaan diri dengan aktivitas yang disukai setelah menyelesaikan kegiatan non-disukai.

5. Menyediakan kesempatan bagi siswa untuk selanjutnya tugas pada satu waktu dan tempat yang jauh dari lingkungan belajar yang asli. Upaya memperkuat tugas di masa depan.

6. Gunakan penghargaan dan that follow penguat alami dari tugas daripada yang tidak terkait dengan atau minimal terkait dengan tugas.

7. Gunakan informasi daripada aspek mengendalikan penghargaan.

8. Menggunakan hadiah tak terduga dan pujian verbal untuk menjaga motivasi.

9. Hubungan keberhasilan dengan atribut pribadi (kemampuan dan usaha).

10.Memberikan kesempatan untuk kontrol keberhasilan atas situasi learnering.

11.Memberikan kesempatan untuk keterlibatan lebih lanjut dengan topik (s) yang siswa sudah tahu tentang atau percaya masuk

12. Meningkatkan disonansi untuk merangsang minat dan motivasi dilanjutkan dengan:

a. Menyediakan informasi sedikit di luar "jangkauan penerimaan"

b. Menggunakan situasi yang baru dan tak terduga atau peristiwa.

c. Menggunakan bahan orang dan emosional dan situasi.

Dengan demikian bahwa dalam proses perencanaan pembelajaran yang bernuansa motivasi, sangat diperhatikan apa yang dibutuhkan oleh siswa, atau dengan kata lain perlu, yaitu menurut Ivor K. Davies (Editor Romiszowki) diidentifikasikan kebutuhan siswa, kemudian nanti dapat terlihat apa dampak perencananan tersebut dalam pembelajaran. (Romiszowki; 1991: 39)

Dalam gambar tersebut dapat dijelaskan, mulai dari identifikasi kebutuhan siswa, menetapkan tujuan, menyeleksi pengalaman pembelajaran, seleksi isi, implementasi program, dan evaluasi serta revisi. Jika diamati dari bagan tersebut, adalah yang ada di dalam lingkaran hitam, ada tiga hal yang perlu diperhatikan, yaitu: identifikasi, evalusi dan revisi, serta dampak perencanaan dalam aktivitas pembelajaran, untuk lebih jelasnya dapat dilihat dari gambar berikut ini. 


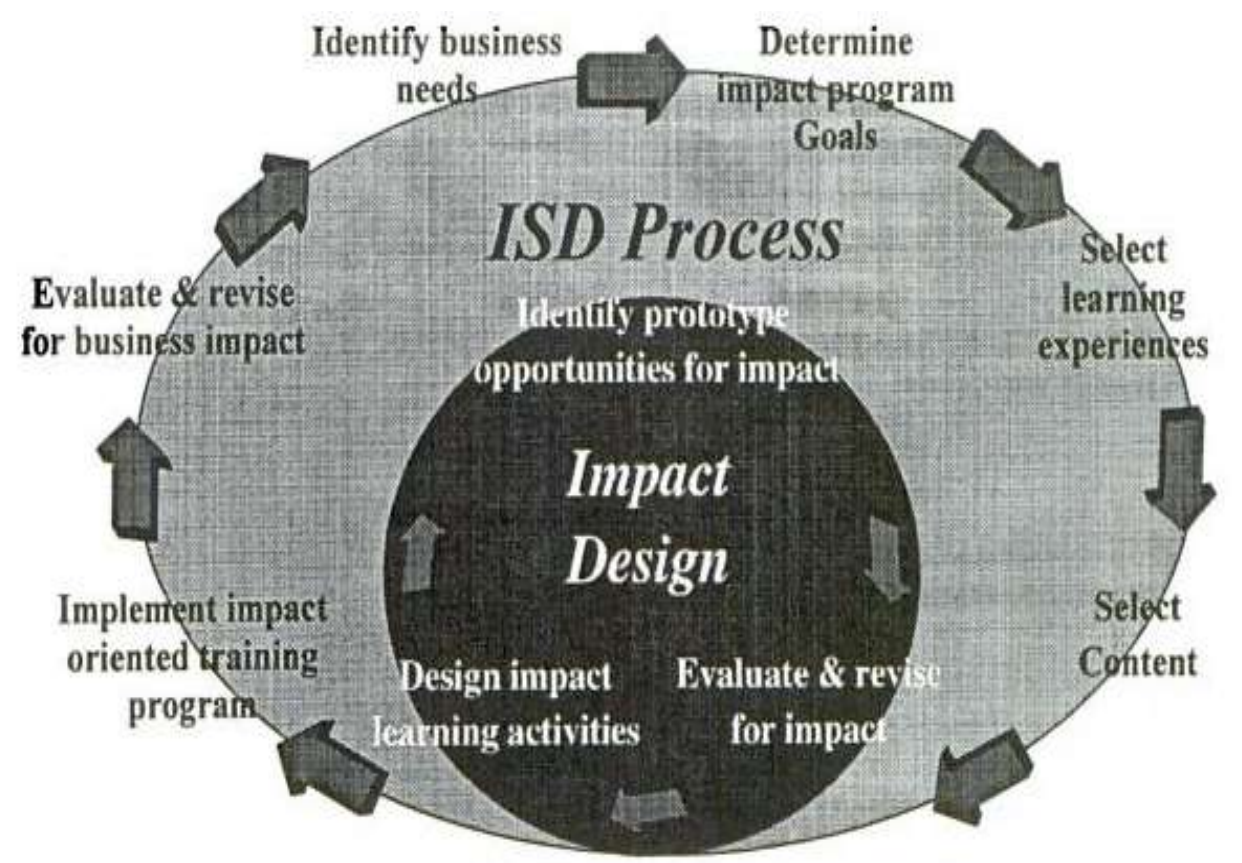

Figure 4. Instructional systems design for impact.

\section{PENUTUP}

Berdasarkan penjelasan di atas dapat disimpulkan bahwa motivasi sering dikaitkan dengan prestasi akademik sebagai pengaruh dalam kesuksesan siswa atau kegagalan. Bahkan kegagalan siswa untuk belajar sebagian besar karena kurangnya minat atau kurangnya motivasi. Untuk memperbaiki efek kerusakan yang disebabkan oleh kurangnya motivasi, untuk meningkatkan motivasi misalnya, memberikan penghargaan dan pujian, memberikan pengaturan pendidikan yang memotivasi dan kondusif untuk belajar, dan mengembangkan bahan-bahan yang merangsang dan menyenangkan. Hasil akhir dari pembelajaran tersebut adalah untuk meningkatkan kompetensi akademik dengan meningkatkan prestasi peserta didik melalui motivasi.

Motivasi merupakan kekuatan yang mendorong seseorang melakukan sesuatu untuk mencapai tujuan. Kekuat- an ini pada dasarnya dirangsang oleh berbagai macam kebutuhan, seperti: keinginan yang hendak dipenuhinya, tingkah laku, tujuan dan umpan balik. Proses interaksi tersbut sebagai produk motivasi.

Melalui pembelajaran kooperatif yang memerlukan pendekatan pengajaran penggunaan kelompok kecil siswa untuk bekerja sama dalam memaksimalkan kondisi belajar dalam mencapai tujuan belajar.

Berdasarkan model pembelajaran kooperatif ini, guru lebih berperan sebagai fasilitator yang berfungsi sebagai jembatan penghubung ke arah pemahaman yang lebih tinggi, dengan catatan siswa sendiri. Guru tidak hanya memberikan pengetahuan pada siswa, namun juga harus membangun membangun dalam pikirannya. Siswa mempunyai kesempatan untuk mendapatkan pengalaman langsung dalam menerapkan ideide mereka, hal tersebut merupakan kesempatan bagi siswa untuk mene- 
mukan dan menerapkan ide-ide siswa sendiri.

Proses pembelajaran kooperatif dibentuk dengan jumlah siswa antara 4 sampai 6 orang siswa. Dengan pembelajaran kooperatif banyak unsur yang perlu perhatikan disamping materi yang disajikan dalam pembelajaran. Ketika kelompok telah dibentuk, maka kerja selanjutnya adalah siswa menentukan sendiri siapa yang menjadi ketua kelompok, untuk mengatur kelompoknya, dengan prinsip kerja tim. Sebab yang dibangun dalam kooperatif adalah kesadaran untuk menerima, dengan

\section{DAFTAR RUJUKAN}

Barbara L. Martin dan Lestie J. Briggs, 1986, The Affective dan Conitive Domains: Integration for Instruction And Research, Educational Technology Publications Englewood Cliffs, New Jersey.

Krathwohl, 1964, Taxonomy of Educational Objective, : Affective Domain, New York: Longman.

Slavin 1983. Pembelajaran kooperatif. Maryland: John Hopkins University.

Ismail 2003. Media Pembelajaran (Model-model Pembelajaran). Jakarta: ProyekPeningkatan Mutu SLTP hal.181

Nurul Hayati2000. Pembelajaran Kooperatif. Surabaya: Unesa University Press.

http://edtech.kennesaw.edu/intech/coope rativelearning.htm.

Isbandi Rukminto, 1994, Psikologi, Pekerjaan Sosial dan Ilmu Kesejahteraan Sosial, Jakarta: PT. melihat apa yang terjadi dalam belajar sehingga dapat membangkitkan motivasi pada diri siswa dalam tim tersebut.

Ada yang menarik dalam pembelajaran kooperatif, yaitu terlihat jelas nuansa ranah kognitif dan afektif. Ketika orang menerima untuk bekerjasama, menghargai pendapat orang lain, santun di dalam menyampaikan ketidaksenangan, aktif mendengarkan pendapat kelompok lain, adalah ranah afektif. Sedangkan ikut bertanya, membuat ringkasan, ikut menafsirkan, mengatur dan mengorganisir serta bertanggung jawa adalah ranah kognitif.

\section{Grafindo Persada.}

Gerungan. W.A, 1996, Psikologi Sosial, Bandung: PT Erisco.

Barbara L. Martin dan Lestie J. Briggs, 1986, The Affective dan Conitive Domains: Integration for Instruction And Research, Educational Technology Publications Englewood Cliffs, New Jersey.

Sardjiman, 2005, Interaksi dan Motivasi Belajar Mengajar, Jakarta: PT RajaGrafindo Persada.

Johnson dan Johnson 1994, Teaching and learning cooperative.

Louisell dan Descamps 1992. Developing a Teaching Style. New-York. HarperCollins Publishers.

Nur dkk.(2000). Pembelajaran Kooperatif. Surabaya: Unesa University Press, hal. 20

Romiszowki; 1991,Instructional Development Paradigm. 